\title{
Epidemiology and Risk Factors of Hepatocellular Carcinoma in Egypt
}

Ahmed Abudeif Abdelaal

\author{
Lecturer of Tropical Medicine and Gastroenterology, Sohag Faculty of Medicine, Sohag
}

University.

\begin{abstract}
Hepatocellular carcinoma (HCC) is the most prevalent primary cancer of the liver accounting for $75 \%$ to $85 \%$ of primary liver cancers worldwide. It is the sixth most prevalent cancer in the globe and the fourth most prevalent cause of death from cancer, it occurs in males 2 to 3 times higher than in females. Geographical distribution of HCC varies throughout the world being highest in East Asia and sub-Saharan Africa. In general, HCC risk factors include viral infections, cirrhosis, alcohol, non-alcoholic fatty liver disease (NAFLD), aflatoxins, diabetes mellitus and obesity. Egypt has the world's second highest incidence of $\mathrm{HCC}$, which can be ascribed to the elevated prevalence and complications of the hepatitis $\mathrm{C}$ virus (HCV). An active surveillance for $\mathrm{HCC}$ together with screening programs for $\mathrm{HCV}$ and initiation of antiviral therapy with new potent direct acting antivirals (DAAs) at an early stage for patients with chronic HCV infection are the most important steps to reduce the risk of HCC in Egypt.
\end{abstract}

Keywords: Hepatocellular carcinoma;HCC;GLOBOCAN 2018;Epidemiology;Risk factors

Global incidence, prevalence and risk factors of $\mathrm{HCC}$

Hepatocellular carcinoma (HCC) accounts for $75 \%-85 \%$ of the world's primary liver cancers (1). It is the sixth most prevalent cancer in the globe and the fourth most prevalent cause of death from cancer, accounting for $4.7 \%$ of all cancers in 2018, with approximately 841,000 new cases of liver cancer and 782,000 deaths annually. HCC occurs in males 2-3 times higher than in females. $\mathrm{HCC}$ in males is the world's fifth most frequently diagnosed cancer, but the second most common cause of death from cancer. HCC is the ninth most frequently diagnosed cancer in females and the sixth major cause of death from cancer (Figure 1) (2).

HCC distribution varies between world's regions where, rates are the highest in East Asia, Sub-Saharan Africa, North and West Africa and the lowest in North,
Central and Eastern Europe and SouthCentral Asia (3).

As regards individual countries, Mongolia had the highest liver cancer rate in 2018 (approximately four times that of males in China and the Republic of Korea), followed by Egypt (Table 1) (2).

The heavy burden of HCC in Mongolia, could be attributed to $\mathrm{HBV}$, HCV infections and HBV carriers' coinfections with $\mathrm{HCV}$ or hepatitis $\delta$ virus as well as alcohol abuse (4).

In an underlying population, the global age distribution of HCC cases is related to the prevalent type of viral hepatitis and the age at which it was obtained. In high-incidence areas, the most prevalent cause is HBV transmitted during labour, the diagnosis of $\mathrm{HCC}$ is about a decade earlier compared to areas where $\mathrm{HCV}$ is the most prevalent etiology obtained later in life (5). 


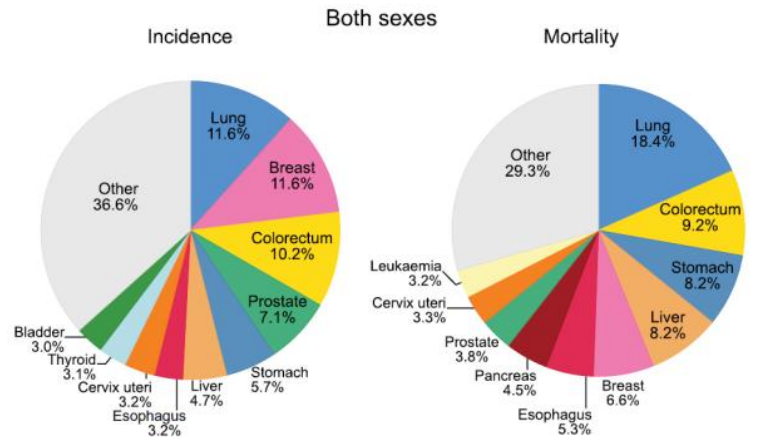

Figure (1): Pie charts show the distribution of cases and deaths for the 10 most prevalent malignancies for both sexes in 2018 (2).

Viral infections (particularly chronic HBV and HCV), cirrhosis, alcohol and non-alcoholic fatty liver disease (NAFLD) are major risk factors for HCC. Aflatoxin, family history and genetic factors, diabetes, obesity, and smoking are additional risk factors (6).

\begin{tabular}{|c|c|c|c|c|c|}
\hline \multicolumn{2}{|c|}{ Both sexes } & \multirow{2}{*}{$\begin{array}{l}\text { Males } \\
\text { Country }\end{array}$} & \multirow[b]{2}{*}{$\begin{array}{l}\text { ASR } \\
\text { per } \\
100000\end{array}$} & \multicolumn{2}{|l|}{ Females } \\
\hline Country & $\begin{array}{c}\text { ASR } \\
\text { per } \\
\mathbf{1 0 0 0 0 0}\end{array}$ & & & Country & $\begin{array}{l}\text { ASR } \\
\text { per } \\
100000\end{array}$ \\
\hline Mongolia & 93.7 & Mongolia & 117 & Mongolia & 74.1 \\
\hline Egypt & 32.2 & Egypt & 49 & Egypt & 16.7 \\
\hline Gambia & 23.9 & Vietnam & 39 & Guinea & 16.3 \\
\hline Vietnam & 23.2 & Gambia & 36.5 & Guatemala & 14.1 \\
\hline Laos & 22.4 & Cambodia & 34.6 & Laos & 13.1 \\
\hline Cambodia & 21.8 & Laos & 33.4 & Cambodia & 12.7 \\
\hline Guinea & 21.8 & Thailand & 32.2 & Gambia & 12 \\
\hline Thailand & 21 & Guinea & 27.9 & Liberia & 11.7 \\
\hline China & 18.3 & $\begin{array}{l}\text { South } \\
\text { Korea }\end{array}$ & 27.7 & Thailand & 11.4 \\
\hline $\begin{array}{l}\text { South } \\
\text { Korea }\end{array}$ & 17.3 & China & 27.6 & $\begin{array}{l}\text { Papua } \\
\text { New } \\
\text { Guinea }\end{array}$ & 10 \\
\hline
\end{tabular}

Table (1): Country-specific age-standardized rates for cancers of the liver in 2018 for both sexes, males, and females (2).

The most important risk factors for $\mathrm{HCC}$ differ from region to region. The main factors are chronic $\mathrm{HBV}$ infection and aflatoxins in most high-risk HCC regions (China, Eastern Africa), whereas in other nations (Japan, Egypt), HCV infection is probable to be the predominant cause (7).

The growing prevalence of obesity in low-risk HCC regions is regarded a contributing factor to the observed growing incidence of HCC (8).
In developed countries, $\mathrm{HBV}$ and $\mathrm{HCV}$ account for approximately $19 \%$ of infection-related HCC cases and $32 \%$ in developing countries (3).

HCC occurs in the setting of cirrhosis in $80-90 \%$ of cases (5).

\section{HCC in Egypt: epidemiology and risk factors}

In Egypt, HCC is the most prevalent malignancy in men, the $2^{\text {nd }}$ most prevalent in women and the most prevalent malignancy in both sexes combined (Figure 2) (9).

Hospital surveys revealed general rise in the relative frequency of all liver-related malignancies (> 95\% as HCC) from about 4\% in 1993 to $7.3 \%$ in 2003. (10).

The incidence of HCC is increased to $19.7 \%$ of the total cancer cases $(25,399$ cases are HCC) at 2018. The 2018 incidence data were collected from Aswan, Damietta and Minia Cancer Registries; it was calculated by weighted / simple average of the recent local population rates for 2018 (11).

$\mathrm{HCC}$ is the major cause of death from cancer in Egypt $(32.35 \%$ of the total cancer deaths). Mortality data were available through the World Health Organization (WHO), while national incidence data were estimated by modelling using incidence; mortality ratios from cancer records in neighboring countries (11).

This rising incidence of $\mathrm{HCC}$ may be due to the increased frequency of HCV and its complications, advances in screening programs and diagnostic methods, together with the rising rate of survival among cirrhotics, enabling some patients to develop HCC. The increased incidence of HCC among urban inhabitants could be a consequence to improved access to medical services, leading to an underestimation of $\mathrm{HCC}$ in rural communities $(\mathbf{1 2}, \mathbf{1 3})$. 
Studies in Egypt revealed the rising role of $\mathrm{HCV}$ infection in liver cancer etiology, estimated to account for 40$50 \%$ of instances, and the decreasing impact of HBV and HBV/HCV infection (25\% and $15 \%$, respectively) $(\mathbf{1 0}, \mathbf{1 4})$. Unlike HBV which can induce HCC by direct integration of its genome into the human DNA; HCV is a single-stranded nonintegrating, RNA virus which causes repetitive hepatocellular injury that can induce malignant transformation of hepatocytes as injured cells regenerate (15).

The incidence of developing $\mathrm{HCC}$ in $\mathrm{HCV}$ patients is 15-20 times greater than in uninfected patients. HCC rarely occurs in the absence of significant fibrosis or cirrhosis (16).

The highest prevalence of HCV infection in the globe is in Egypt (17).

The 2008 Egyptian Demographic Health Survey (EDHS) revealed $14.7 \%$ national seroprevalence among those between 15 and 59 years of age, with $9.7 \%$ viraemic prevalence in this age group that increased with age and was greater among men than among women in all age groups studied (18).

The 2015 EDHS was conducted to reestimate $\mathrm{HCV}$ prevalence, including age groups 1-59 years. Seroprevalence in age groups 15-59 years was $10 \%$ and prevalence in age groups $<15$ years was $0.4 \%$, bringing complete seroprevalence to $6.3 \%$ in those $<60$ years of age and viraemic prevalence to $4.4 \%$ (7\% in age groups 15-59 years of age and $0.2 \%$ in those $<15$ years of age) (19).
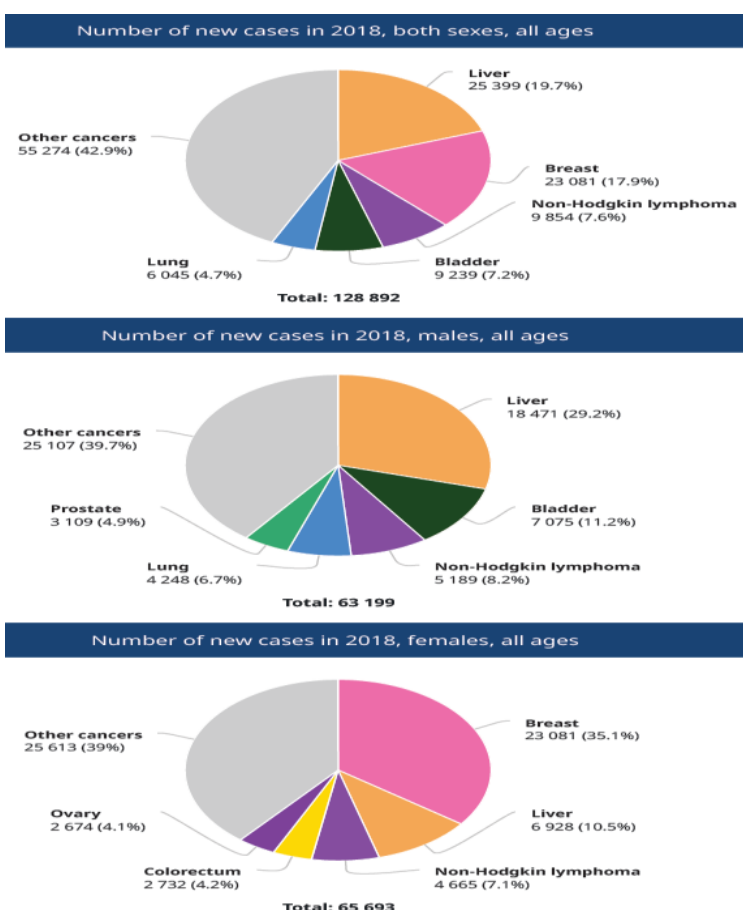

Figure (2): Incidence of liver cancer in Egypt for both sexes, males and females, GLOBOCAN 2018 (9).

The origin of the Egyptian HCV epidemic was ascribed to mass parenteral anti-schistosomiasis treatment (PAT) campaigns in the 1950s-1980s, with maximum transmission likely occurring in the 1960s-1970s. During PAT campaigns, glass syringes re-usage and lax sterilization techniques appear to have caused extensive $\mathrm{HCV}$ infection $(20,21)$.

Despite the broad spread introduction of praziquantel in 1982 with consequent decline in PAT usage (22), HCV transmission persisted in Egypt through several practices including blood transfusion, injections, dental therapy, surgery and invasive medical practices; and instrumental delivery $(\mathbf{2 3}, \mathbf{2 4})$. 
SOHAG MEDICAL JOURNAL

Vol. 23 No. 3 July 2019
The emergence of new direct acting antivirals (DAAs) with their strong efficiency and very satisfactory safety profiles will lead significantly to reducing the burden of disease induced by $\mathrm{HCV}$ infection and hence reduction of $\mathrm{HCC}$ cases in the future (25).

\section{Conclusion}

The incidence of $\mathrm{HCC}$ is rising, and the mortality rate is very high. $\mathrm{HCC}$ is a serious health problem in Egypt and its incidence is increasing, related mainly to chronic infection with HCV. The high incidence and prevalence of $\mathrm{HCV}$ infection in Egypt makes screening programs and initiation of antiviral therapy with new potent DAAs at an early stage together with universal blood products screening, safe injection techniques, and treatment of injection drug users an effective means for reduction of $\mathrm{HCV}$ infection and hence HCC incidence. Additionally, surveillance of chronic HCV patients by ultrasonography enables early detection of small HCCs where curative treatment still an option.

\section{References}

1. Jemal A, Bray F, Center MM, et al. Global cancer statistics. CA Cancer J Clin 2011; 61: 69-90.

2. Bray F, Ferlay J, Soerjomataram I, et al. Global cancer statistics 2018: GLOBOCAN estimates of incidence and mortality worldwide for 36 cancers in 185 countries. CA Cancer J Clin 2018; 68: 394-424.

3. Torre LA, Bray F, Siegel RL, et al. Global cancer statistics, 2012. CA Cancer J Clin 2015; 65: 87-108.

4. Chimed T, Sandagdorj T, Znaor A et al. Cancer incidence and cancer control in Mongolia: results from the National Cancer Registry 2008-2012. Int J Cancer 2017; 140: 302-309.

5. Mittal S, El-Serag HB. Epidemiology of HCC: Consider the Population. J Clin Gastroenterol 2013; 47: S2-S6.
6. Tang A, Hallouch O, Chernyak V, et al. Epidemiology of hepatocellular carcinoma: target population for surveillance and diagnosis. Abdom Radiol 2018; 43: 13-25.

7. Kew MC. Hepatocellular carcinoma in developing countries: Prevention, diagnosis and treatment. World $\mathbf{J}$ Hepatol 2012; 4(3): 99-104.

8. Marengo A, Rosso C, Bugianesi E. Liver cancer: connections with obesity, fatty liver, and cirrhosis. Annu Rev Med 2016; 67: 103-117.

9. Ferlay J, Ervik M, Lam F, et al. Global Cancer Observatory: Cancer Today. Lyon, France: International Agency for Research on Cancer. 2018. Available from: https://gco.iarc.fr/today, accessed [31 May 2019].

10. El-Zayadi AR, Badran HM, Barakat EM, et al. Hepatocellular carcinoma in Egypt: a single center study over a decade. World J Gastroenterol 2005; 11: 5193-5198.

11. Ferlay J, Colombet $M$, Soerjomataram I, et al. Estimating the global cancer incidence and mortality in 2018: GLOBOCAN sources and methods. Int J Cancer 2019; 144: 19411953.

12. El-Serag HB. Epidemiology of hepatocellular carcinoma. Clin Liver Dis 2001; 5: 87-107.

13. Omar A, Abou-Alfa GK, Khairy A, et al. Risk factors for developing hepatocellular carcinoma in Egypt. Chin Clin Oncol 2013; 2: 43.

14. Hassan MM, Zaghloul AS, El-Serag $\mathbf{H B}$, et al. The role of hepatitis $\mathrm{C}$ in hepatocellular carcinoma - A case control study among Egyptian patients. J Clin Gastroenterol 2001; 33: 123126.

15. Prenner SB, Kulik L. Hepatocellular carcinoma. In: Sanyal AJ, Boyer TD, Lindor KD, Terrault NA (Eds.), Zakim and Boyer's Hepatology: A Textbook of Liver Disease, $7^{\text {th }}$ ed. Philadelphia: Elsevier, 2018; 668-692. 
16. El-Serag HB, Kanwal F. Epidemiology of hepatocellular carcinoma in the United States: where are we? Where do we go? Hepatology 2014; 60: 1767-1775.

17. Blach S, Zeuzem S, Manns M, et al. Global prevalence and genotype distribution of hepatitis $\mathrm{C}$ virus infection in 2015: a modelling study. Lancet Gastroenterol Hepatol 2017; 2: 161-176.

18. El-Zanaty F, Way A. Egypt Demographic and Health Survey 2008. Cairo, Egypt: Ministry of Health, ElZanaty and Associates, and Macro International 2009; 1-431.

19. Gomaa A, Allam N, Elsharkawy A, et al. Hepatitis $\mathrm{C}$ infection in Egypt: prevalence, impact and management strategies. Hepat Med 2017; 9: 17-25.

20. Strickland G. Liver disease in Egypt: hepatitis $\mathrm{C}$ superseded schistosomiasis as a result of iatrogenic and biological factors. Hepatology 2006; 43: 915-922.
21. Yahia M. Global health: A uniquely Egyptian epidemic. Nature 2011; 474: S12-S13.

22. Rao MR, Naficy AB, Darwish MA, et al. Further evidence for association of hepatitis $\mathrm{C}$ infection with parenteral schistosomiasis treatment in Egypt. BMC Infect Dis 2002; 2: 29.

23. Medhat A, Shehata M, Magder LS, et al. Hepatitis $\mathrm{C}$ in a community in Upper Egypt: risk factors for infection. Am J Trop Med Hyg 2002; 66: 633638.

24. Mohamoud YA, Mumtaz GR, Riome S, et al. The epidemiology of hepatitis $\mathrm{C}$ virus in Egypt: a systematic review and data synthesis. BMC Infect Dis 2013; 13: 288.

25. Boesecke C, Wasmuth JC. Hepatitis C. In: Mauss S, Berg T, Rockstroh JK, Sarrazin C, Wedemeyer H. (Eds.), Hepatology A clinical textbook, $8^{\text {th }}$ ed. Koblenz: Druckerei Heinrich $\mathrm{GmbH}$, 2017; 55-67. 